\title{
Niezgoda i dialog
}

\section{|Agnieszka Rypel}

Książka Marii Kwiatkowskiej Ratajczak Docenić szkołę. Dydaktyczna teoria i metodyczna praktyka ${ }^{1}$, jak wskazuje tytuł, porusza kwestie fundamentalne dla społecznego postrzegania polskiej edukacji. W centrum zainteresowania Autorki (tak w refleksji teoretycznej, jak i ściśle pragmatycznej) znalazły się relacje między tradycją dydaktyczną, a współczesnym podejściem do nauczaniem szkolnego przedmiotu „język polski”. Tekst składa się ze wstępu i dwóch części: Po stronie uczniów, nauczycieli i dydaktyków oraz Szkolna wspólnota dydaktyczna. Ich tytuły wyraźnie wskazują na podejście Autorki do przedstawianych problemów - docenienie właściwych podmiotów edukacji, uznanie ich sprawczości oraz wspólnotowości łączących je relacji. Na przyjętą w książce hierarchię wartości wskazuje także tytuł zakończenia Uczniowskie postscriptum. O głębokim i długim namyśle Autorki nad podejmowanymi zagadnieniami, a zarazem o aktualności jej konstatacji świadczy fakt, że sześć z dziewięciu zamieszczonych w książce esejów zostało już opublikowanych w latach 2018-2020 w różnych czasopismach i monografiach. Uzupełnione i zmodyfikowane teksty Autorka opatrzyła wstępem, który stanowi swoistą wykładnię myśli przewodniej książki i łączy poszczególne szkice w spójną całość.

Lektura publikacji pozwala wyróżnić dwa słowa klucze, które pojawiają się w obydwu częściach książki, są to "niezgoda” oraz „dialog”, i to w kontekście tych właśnie pojęć chciałabym odnieść się do przedstawionych $\mathrm{w}$ poszczególnych tekstach zagadnień oraz do sposobu ich ujęcia. Moje podejście do recenzowanych esejów ma więc przede wszystkim charakter bardziej sproblematyzowany niż sprawozdawczo-oceniający. Muszę przyznać, że jako recenzentka jestem w komfortowej sytuacji, ponieważ

${ }^{1}$ Kwiatkowska-Ratajczak M., 2021, Docenić szkołę. Dydaktyczna teoria i metodyczna praktyka, Poznań. 
podzielam poglądy Autorki i ze zdecydowaną większością jej sądów w pełni się zgadzam. Potrafię także zrozumieć bardzo osobisty i emocjonalny miejscami ton Jej wypowiedzi. Trzeba jednak przyznać, że w polemice Autorka nigdy nie przekracza miary, którą powinien cechować się dyskurs publiczny, a wszystkie swoje tezy, niejednokrotnie niewygodne dla decydentów, popiera przemyślanymi argumentami.

Pierwsze ze wspomnianych słów-kluczy to niezgoda. Przede wszystkim jest to niezgoda na zrywanie związków zapewniających ciągłość rozwoju myśli uniwersyteckiej i zacieranie głębokich relacji Mistrz - Uczeń. Lekceważenie przez władze oświatowe przemyśleń i ustaleń badawczych poczynionych w przeszłości (ale i obecnie) przez wybitnych akademików oraz twórczych nauczycieli, którzy najlepiej znają realia funkcjonowania szkoły i ich odziaływanie na konkretnych, a nie abstrakcyjnych uczniów, prowadzi do, jak to ujmuje Autorka, „polonistycznego regresu”. Powierzchowne przywoływanie autorytetów, zarówno uniwersyteckich, jak i nauczycielskich oraz całkowite pomijanie przez decydentów oczekiwań i rzeczywistych potrzeb uczniów, a także realnych uwarunkowań społeczno-kulturowych sprawia, że cele ujęte w aktualnych dokumentach oświatowych są na ogół deklaratywne i oderwane od rzeczywistości, choć pozornie do niej nawiązują. Autorka wyraża zatem swój głęboki sprzeciw wobec negowania podmiotowości ucznia, ale i nauczyciela, któremu podstawa programowa (ale dodajmy, również firmowana przez państwo egzaminacyjna praktyka sprawdzania zunifikowanej wiedzy i w niewielkim stopniu umiejętności) ogranicza pole samodzielnego działania, a mniej kreatywnym polonistom przyzwala na sztampowość i powielanie banałów. Można powiedzieć, że Autorka paradoksalnie nie zgadza się na brak niezgody - niezgody na jednomyślność, brak dyskusji i samodzielnych poszukiwań, na manipulowanie hierarchią wartości zależnie od aktualnych wizji decydentów, na zunifikowane interpretacje literatury i szeroko rozumianej kultury oraz na bardzo ograniczone podejście do rozmaitych aspektów międzykulturowości.

Niezgoda dotyczy również sposobu przygotowania, czy raczej nieprzygotowania, przyszłych polonistów do pracy we współczesnej szkole. W przekonaniu Autorki ich uchybienia i zaniedbania w dużym stopniu wynikają z anachronicznego już modelu kształcenia (dodajmy, że również podnoszenia kwalifikacji). Kwestia ta moim zdaniem jest warta omówienia przez Autorkę w równie wnikliwy sposób w kolejnych publikacjach, tym bardziej że już teraz nauczycielami zostają osoby należące do screen-generation. Nauczyciele akademiccy pracujący z przyszłymi polonistami zauważają, jak silnie w ich sposobie myślenia, mówienia, pisania i stosunku do rzeczywistości odzwierciedlają się współczesne procesy językowo-kulturowe. To z perspektywy osób urodzonych i poddanych procesom pierwotnej i wtórnej socjalizacji jeszcze przed rozpoczęciem rewolucji cyfrowej, wiele technologii jest „nowych”, ze swojego punktu widzeniach oceniają też jako 
niewłaściwe współczesne praktyki komunikacyjno-językowe oraz formy uczestniczenia w kulturze - przyszli nauczyciele nie znają świata, w którym by tych zjawisk nie było. Jaki kształt powinna mieć zatem dydaktyka akademicka, aby postulowane koncepcje kształcenia językowego znalazły swych realizatorów w praktyce edukacyjnej?

Konstatacje Autorki nie ograniczają się wyłącznie do krytycznej analizy aktualnej rzeczywistości edukacyjnej. Afirmatywna część jej rozważań koncentruje się wokół drugiego z wymienionych słów kluczy, a mianowicie „dialogu”. Przede wszystkim jest to dialog z Mistrzami. Autorka, sama już Mistrzyni, przywołuje przede wszystkim swoich wybitnych poznańskich Profesorów - Antoniego Smuszkiewicza i Edwarda Balcerzana, których pracami się inspiruje, tworząc na ich kanwie własne koncepcje odzwierciadlające współczesny kontekst edukacyjny. W jej tekstach pojawiają się również liczne odwołania do ciągle aktualnych ustaleń kolejnego Mistrza wielu pokoleń polonistów, Zenona Urygi. Autorka prowadzi także dialog z wybitnymi autorytetami, m.in. Kazimierzem Wóycickim, Janem Polakowskim, Ireną Wojnar, Janem Błońskim, Mieczysławem Inglotem i Tadeuszem Patrzałkiem. Przyznaję, że zabrakło mi w tym zestawieniu Marii Dudzik, której prace dotyczące aksjologii w nauczaniu języka polskiego wniosły wielki wkład w rozwój dydaktyki polonistycznej, a przecież Autorka kwestiom aksjologicznym poświęca dużo uwagi. Warte podkreślenia jest nawiązywanie dialogu z przedstawicielami młodszego pokolenia badaczy, których - moim zdaniem - można również uważać za Mistrzów - z Zofią Agnieszką Kłakówną, Wiesławą Wantuch, Ryszardem Koziołkiem - ale też z naukowcami, którzy rozpoczynają swą drogę do mistrzostwa, np. Piotrem Kołodziejem, Krzysztofem Kocem czy Markiem Pieniążkiem.

Jednak szczególne miejsce w kształtowaniu postawy badawczej Autorki oraz w jej spojrzeniu na funkcje i znaczenie edukacji polonistycznej zajmuje Bożena Chrząstowska, której koncepcje stanowią kluczowy punkt odniesień poznańskiej Badaczki. Bliska współpraca z Mistrzynią kilku pokoleń polonistów oraz obcowanie z Jej dziełami uwidaczniają się przede wszystkim w podejściu do prezentowanych problemów, tzn. odwadze, bezkompromisowości, docenianiu nowatorskich rozwiązań, ale też trosce, aby w działaniach dydaktycznych widzieć przede wszystkim ich najważniejsze podmioty - Uczniów i Nauczycieli.

Autorka wskazuje również na znaczenie dialogu kultur w budowaniu własnej tożsamości oraz interpretowaniu literatury i sztuki. Szczególne miejsce przypisuje kulturze lokalnej. Ten wątek refleksji Badaczki jest niezwykle ważny w dobie rozwoju tzw. nowego regionalizmu, dla którego z pewnością warto znaleźć miejsce we współczesnej szkole, czego zresztą zawarte w tomie teksty doskonale dowodzą. Autorka swoje rozważania popiera przedstawieniem inicjatywy nauczycieli i uczniów jednego z poznańskich liceów, którzy przygotowali projekt poświęcony setnej rocznicy 
powstania wielkopolskiego. Licealiści ukazali ten zryw niepodległościowy przez pryzmat rodzinnych wspomnień i pamiątek po powstańcach.

Dialog kultur jest również przedmiotem szkicu Stare obrazy i nowe fotografie a dydaktyczne ożywianie kulturowego archiwum. Autorka przedstawia w nim przykład projektu, w którym licealiści budują swoją tożsamość, obmyślając własne działania intertekstualne i sprawiają, że stworzone przez nich fotografie „rozmawiają” z dziełami sztuki. Chciałbym również podkreślić, że Autorka, która koncentruje się przede wszystkim na kształceniu kulturowym, podejmuje także dialog z ideami prezentowanymi przez lingwodydaktyków, np. w związku z teorią terminów Stanisława Gajdy czy ustaleń Krzysztofa Skibskiego.

Jeden $\mathrm{z}$ zamieszczonych $\mathrm{w}$ książce tekstów Jeden uczeń, dwie szkoły - refleksje o edukacji w Polsce i poza jej granicami skłania mnie do pewnych zastrzeżeń. W moim przekonaniu jego tytuł jest nieco dezinformujący. Po jego przeczytaniu miałam wrażenie, że szkic będzie traktował o nauczaniu dzieci z doświadczeniem migracyjnym, uczących się jednocześnie w polskiej szkole (np. sobotniej lub konsularnej) oraz w szkole kraju przyjmującego. Tymczasem tekst dotyczy raczej konfrontacji edukacyjnych nawyków ucznia wyniesionych z polskiej szkoły z nowymi doświadczeniami zdobywanymi w zagranicznej placówce edukacyjnej. Muszę też przyznać, że według mnie ten tekst, w porównaniu z innymi zamieszczonymi $\mathrm{w}$ tomie, $\mathrm{w}$ niewielkim stopniu odzwierciedla ideę dialogowości, w tym przypadku dotyczącą dialogu między dwiema kulturami edukacyjnymi, bo chyba jednak tak szeroko powinno się traktować przedstawienie dwóch różnych szkół. Choć autorka bardzo dobitnie zastrzega, że Jej celem jest „przypomnienie sprawdzających się mechanizmów dydaktycznych, nie zaś łatwo wartościujące uogólnienia dotyczące polskiej edukacji i tego, czego młody człowiek oraz jego rodzice doświadczyli poza krajem", trudno (przynajmniej mnie) oprzeć się wrażeniu, że takie wartościowanie istnieje.

$\mathrm{Na}$ zakończenie wypada wspomnieć o realizacji tego, co Autorka nazywa metodyką konkretu i czemu poświęcona jest druga część książki. Niektóre z przedstawionych w niej problemów zostały już omówione, tutaj chciałabym podkreślić, że ogromną zaletą, oprócz intersujących przykładów konkretnych działań uczniów i nauczycieli, jest to, że stanowi ona w dużej mierze swego rodzaju kronikę czasów zarazy. Pandemia spowodowała i nadal powoduje zmiany w systemie nauczania, często są one nagłe i trudne do przewidzenia. Książka jest świadectwem, jak ważne jest rozwijanie podmiotowości ucznia i nauczyciela. Tylko dzięki niej możliwe było realizowanie tak wartościowych projektów, jakie przedstawiła oraz interesująco skomentowała Autorka.

Książka Marii Kwiatkowskiej-Ratajczak to pozycja bardzo wartościowa, ważna dla środowisk akademickich i nauczycielskich. Mimo iż składa się z odrębnych całostek, wyróżnia się uporządkowanym tokiem wywodu, 
a wszystkie teksty cechuje nienaganna, elegancka polszczyzna. Autorka trafnie prezentuje diagnozę stanu polskiej edukacji polonistycznej oraz konfrontuje ją zarówno z tradycją dydaktyczną, jak i nowymi propozycjami uprawiania szkolnej polonistyki. Znaczący jest także aplikatywny charakter przedstawionych przez Autorkę rozwiązań.

Polonistyka. Innowacje 
